\title{
Silicic Large Igneous Provinces
}

\author{
School of Earth Sciences \& Geography, Kingston University, Penrhyn Rd, Kingston Upon Thames, Surrey KT1 2EE United Kingdom. \\ Email:S.Bryan@kingston.ac.uk
}

Large Igneous Provinces (LIPS) are the end-product of huge additions of magma to the continental crust both at the surface and at depth. Since the first categorisation of LIPs by Coffin \& Eldholm (1994), it has been recognised that LIPs are more varied in form, age and character, and this includes the recognition of Silicic LIPs. Silicic LIPs are the largest accumulations of primary volcaniclastic rocks at the Earth's surface with areal extents $>0.1 \mathrm{Mkm}^{2}$ and extrusive and subvolcanic intrusive volumes $>0.25 \mathrm{Mkm}^{3}$. The Late Palaeozoic to Cenozoic Silicic LIP events are the best recognised and are similar in terms of their dimension, crustal setting, volcanic architecture and geochemistry. The Silicic LIPs typically form linear (>2000 km long) volcanic-plutonic belts along volcanic rifted margins or as failed continental rifts. Igneous compositions are volumetrically silicic-dominant (>65 wt\% $\mathrm{SiO}_{2}$ ), but generally show a range of igneous compositions from basalt through to high-silica rhyolite. The rhyolites show transitional within-plate to calc-alkaline or convergent margin geochemical signatures, whereas both low- and high-Ti ( $>2 \mathrm{wt} \% \mathrm{TiO}_{2}$ ) magma types are present in the coeval mafic igneous rocks as commonly observed in continental flood basalt provinces. Several Silicic LIPS form a pre-rift magmatic event along volcanic rifted margins that develop through a consistent temporal pattern of LIP magmatism followed by rifting, uplift and seafloorspreading. The difference between the Silicic LIPs and other continental mafic-dominated LIPs is largely due to different crustal settings. Phanerozoic Silicic LIPs are restricted to continental margins that comprise fertile, hydrous lower crustal materials built up by Phanerozoic subduction. The role of hydrous crustal additions and underplate formed during previous episodes of subduction seem crucial in triggering widespread crustal partial melting, and preventing a dominantly mafic surface expression to LIP events along these palaeo- and active continental margins. Silicic LIPs represent important targets for precious metal mineralisation and host extensive epithermal Au-Ag fields. They have been the sites of many large volume (>1000 $\mathrm{km}^{3}$ dense rock equivalent) silicic explosive eruptions and important sources of ash and aerosol contributions to the stratosphere. Future studies need to integrate their environmental effects with those from similarly large volume flood basalt eruptions.

\section{Introduction}

Three important advances adding to our understanding of the volcanology of Large Igneous Provinces (LIPs) since they were first formally defined by Coffin \& Eldholm (1994) are: 1) the recognition that flood basalt lavas have generally been emplaced as slow advancing, inflated pahoehoe-type lavas, fed from relatively lowrate and long-lived eruptions (e.g., Self et al., 1997; Thordarson \& Self, 1998); 2) that all LIPs contain various proportions of mafic to silicic composition volcanic and volcaniclastic rocks reflecting a variety of volcanic and sedimentary processes and palaeoenvironments, which can be used to test predicted plume-related phenomena (see review in Skilling et al., 2007); and 3) the recognition that continental LIPs can not only have substantial volumes $\left(>10^{4} \mathrm{~km}^{3}\right)$ of silicic igneous rock, but that some LIP-scale igneous provinces are comprised almost entirely by silicic igneous rock (Bryan et al., 2002).

Silicic igneous rocks are an integral part of all continental LIPs from the oldest Precambrian (e.g., Twist \& French, 1983; Thorne \& Trendall, 2001; Blake et al., 2004) to the youngest Cenozoic examples, and are particularly prevalent in the Mesozoic-Cenozoic continental flood basalt provinces and along volcanic rifted margins. In these LIPs, silicic volcanic and volcaniclastic rocks can form substantial parts of the eruptive stratigraphy and represent a significant contribution to the total magmatic output of a LIP (Bryan et al., 2002). Their significance, however, in terms of areal extent, eruptive volume, relative timing of eruptions to and petrogenetic relationships with the flood basalts, and environmental and climatic impacts during LIP emplacement, have generally received less attention in the literature than the associated flood basalt lavas. It is often underappreciated that the scale of some of the individual silicic eruptive units in LIPs is incredibly vast (e.g., in the Paraná-Etendeka where the largest units cover areas $>0.1 \mathrm{Mkm}^{2}$ ) and can be larger than the associated flood basalt lavas, such that they are amongst the largest volume terrestrial eruptive units so far recognized ( $>5000 \mathrm{~km}^{3}$ DRE; Milner et al., 1995; Marsh et al., 2001; Ewart et al., 1998, 2004).

In addition to representing a significant igneous component in continental LIPs, silicic-dominated igneous provinces have been recognised in the last 10 years with eruptive volumes, areal extents and other attributes that are comparable to those of the continental flood basalt provinces and other LIPs (Bryan \& Ernst, submitted), but have low proportions of basalt expressed at the surface. Bryan et al. (2002) defined the term "Silicic Large Igneous Province" (Silicic LIP) to describe these volcano-plutonic provinces of which the Early Cretaceous volcanic rifted margin of eastern Australia (Whitsunday igneous province; Bryan et al., 1997; 2000), and the Jurassic Chon Aike province of South America and the Antarctic Peninsula (Pankhurst \& Rapela,1995; Pankhurst et al., 1998; 2000; Riley \& Leat, 1999) are two wellknown examples (Table 1; Figure 1). 


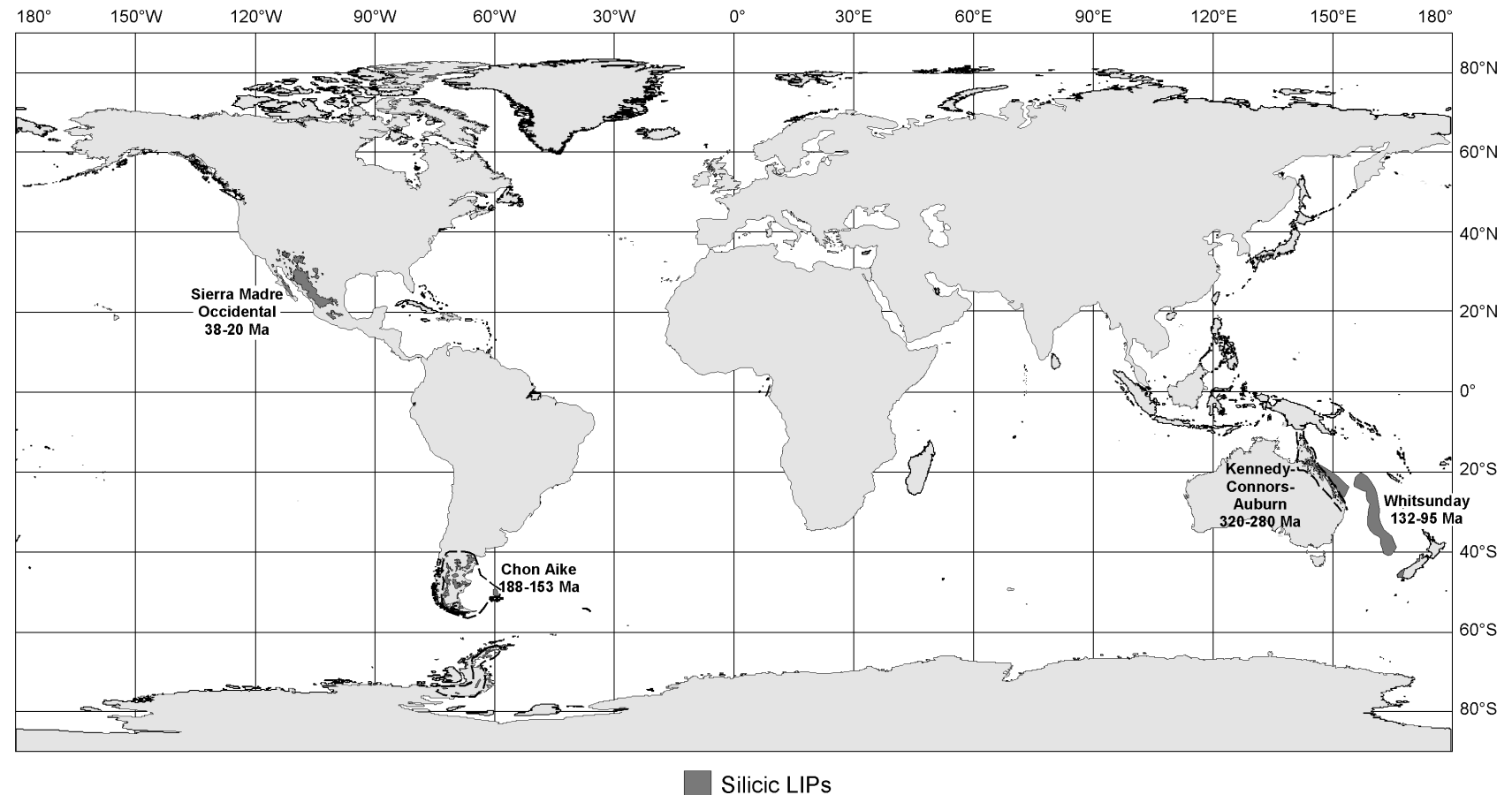

Figure 1 Global distribution of Phanerozoic Silicic LIPs. (Modified from Bryan \& Ernst, submitted). Inferred extents to the Chon Aike and Kennedy-Connors-Auburn provinces are shown by dashed lines.

Table 1 Catalogue of well-defined Phanerozoic Silicic LIPs, ordered in terms of minimum extrusive volumes. From Bryan et al. (submitted).

\begin{tabular}{llllll}
\hline Province & Age (Ma) & $\begin{array}{l}\text { Volume } \\
\left(\mathrm{km}^{3}\right)\end{array}$ & $\begin{array}{l}\text { Dimensions } \\
(\mathrm{km})\end{array}$ & $\begin{array}{l}\text { Magma flux } \\
\left(\mathrm{km}^{3} \mathrm{kyr}-1\right)^{*}\end{array}$ & References \\
\hline $\begin{array}{l}\text { Whitsunday } \\
\text { (Eastern Australia) }\end{array}$ & $\sim 132-95$ & $>2.2 \times 10^{6}$ & $>2500 \times 200$ & $>55$ & $\begin{array}{l}\text { Bryan et al. } \\
(1997 ; 2000 ; \text { Bryan, 2005) }\end{array}$ \\
\hline $\begin{array}{l}\text { Kennedy-Connors-Auburn } \\
\text { (northeast Australia) }\end{array}$ & $\sim 320-280$ & $>5 \times 10^{5}$ & $>1900 \times 300$ & $>12.5$ & $\begin{array}{l}\text { Bain \& Draper (1997); } \\
\text { Bryan et al. (2003) }\end{array}$ \\
\hline $\begin{array}{l}\text { Sierra Madre Occidental } \\
\text { (Mexico) }\end{array}$ & $\sim 38-20$ & $>3.9 \times 10^{2}$ & $>2000 \times 2-500$ & $>22$ & $\begin{array}{l}\text { Ferrari et al. (2002); } \\
\text { Aguirre-Diaz \& Labarthe- } \\
\text { Hernandez (2003) }\end{array}$ \\
\hline $\begin{array}{l}\text { Chon Aike } \\
\text { (SouthAmerica-Antarctica) }\end{array}$ & $188-153$ & $>2.3 \times 10^{2}$ & $>3000 \times 1000$ & $>7.1$ & $\begin{array}{l}\text { Pankhurst et al., } \\
\text { (1998; 2000) }\end{array}$ \\
\hline
\end{tabular}

1-5 Myrs duration. The relatively long life span of the Silicic LIPs is due to the presence of multiple magmatic pulses. During these pulses, a large proportion $\left(\geq 0.1 \mathrm{Mkm}^{3}\right)$ of the magma volume was erupted and/or intruded (Bryan \& Ernst, submitted). Finally, Silicic LIPs share similar crustal settings. They are exclusively continental and sited along palaeo- and active continental margins as they are produced by large-scale crustal anatexis. Several Silicic LIPs occur as a pre-rift magmatic event preceeding the formation of volcanic rifted margins (Figure 2).

The Mesozoic-Cenozoic examples of Silicic LIPs are the best preserved and studied (Table 1; Figure 1), and their characteristics have been summarised by Bryan et al. (2002) and Skilling et al. (2007). As studies over

\section{Silicic LIPs}

Silicic LIPs have several unifying characteristics. First, they have areal extents $>0.1 \mathrm{Mkm}^{2}$ (many are $>0.5 \mathrm{Mkm}^{2}$ ), which is the minimum areal extent for LIPs defined by Coffin \& Eldholm (1994). Second, the Silicic LIPs represent the emplacement of huge volumes of magma throughout the crustal profile and at the Earth's surface; extrusive volumes are $>0.25 \mathrm{Mkm}^{3}$ and up to $\sim 3 \mathrm{Mkm}^{3}$. Third, in terms of igneous compositions, the Silicic LIPs comprise $>80 \%$ by volume of dacite-rhyolite, with transitional calc-alkaline I-type to A-type signatures, and rhyolitic ignimbrite is the dominant (volcanic) lithology. Fourth, the overall duration of Silicic LIP events is up to 40 Myrs, but as observed for many other LIPs, available age data also provide evidence for a transient or pulsed nature to magmatism of

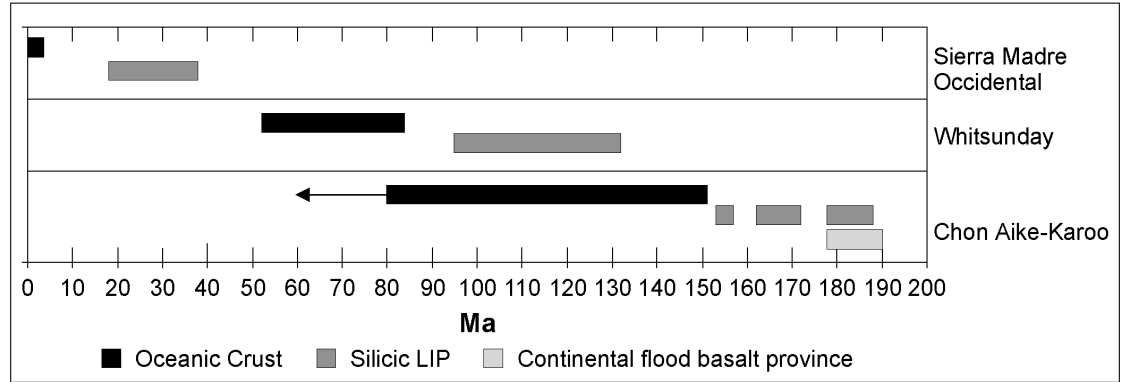

Figure 2 Formation of Silicic LIPs on volcanic rifted margins and the timing of formation of oceanic crust. As with the continental flood basalt provinces, the Silicic LIPs precede breakup and formation of oceanic crust. Compare with figure 3 of Menzies et al. (2002). 

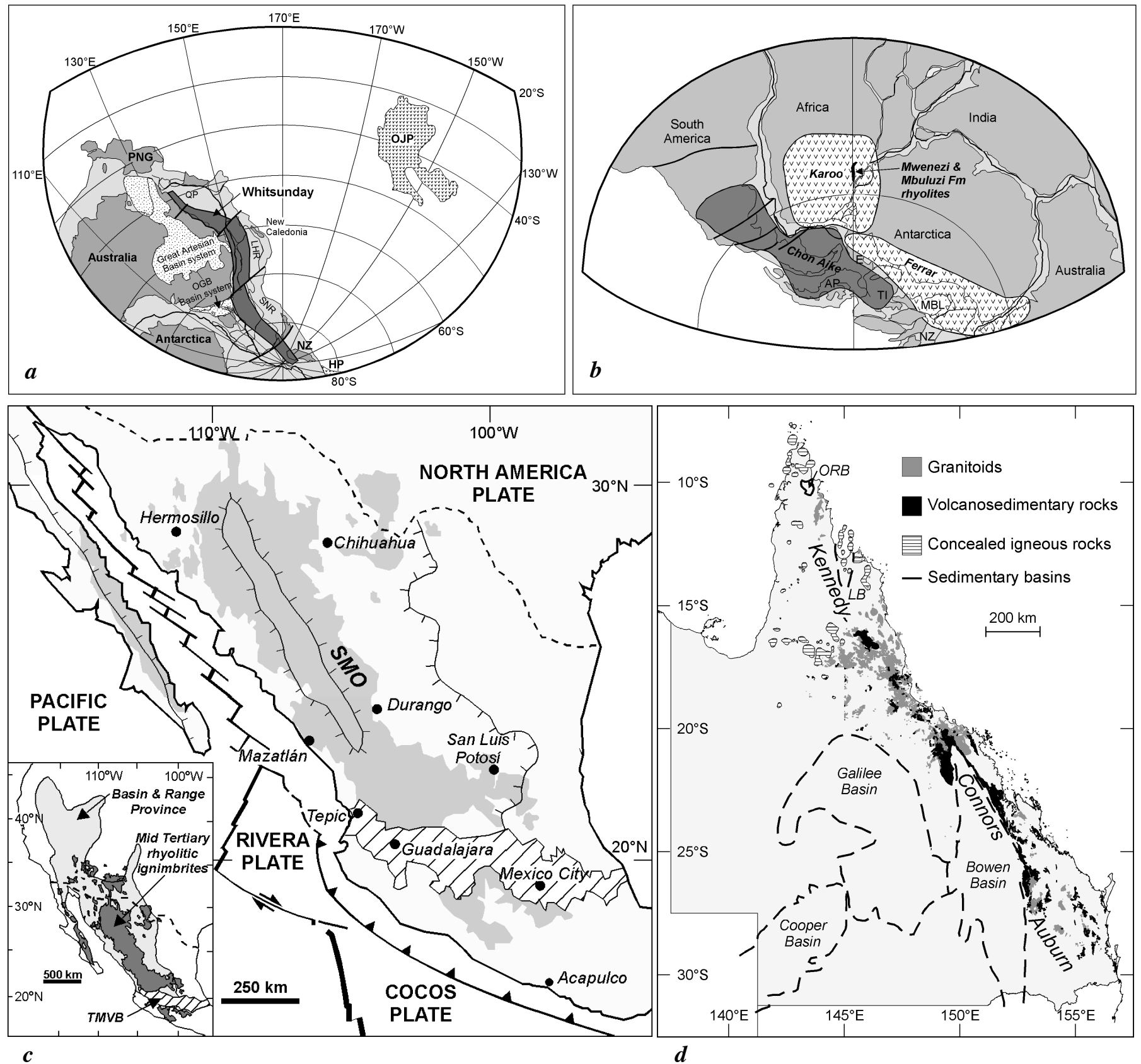

Figure 3 Maps of the Silicic LIPs.

A) Eastern Gondwanaland reconstruction for $\sim 100$ Ma showing the extent of the Whitsunday Silicic LIP along the eastern Australian plate margin, along with the Ontong Java oceanic plateau offshore. Both the Whitsunday Silicic LIP and Ontong Java (+ Hikurangi and Manihiki) Plateaux formed rapidly at $\sim 120 \mathrm{Ma}$. The Whitsunday Silicic LIP was the source of huge volumes $\left(>1.4 \mathrm{Mkm}^{3}\right)$ of coeval, AptianAlbian volcanogenic sedimentary rocks in the neighbouring Great Artesian and Otway/Gippsland basin systems (Bryan et al., 1997). Regional-scale crustal lineaments, which have partitioned deformation and influence drifting along the eastern Gondwanaland margin are also shown. Abbreviations: HP, Hikurangi Plateau; LHR, Lord Howe Rise; NZ, New Zealand; OGB, Otway-Gippsland-Bass; OJP, Ontong Java Plateau; PNG, Papua New Guinea; SNR, southern Norfolk Ridge. Reconstruction is based on Bryan et al. (1997); Gaina et al. (1998; 1999) and Mortimer (2006). The palaeogeographic position of the OJP is based on Kroenke et al. (2004).

B) Gondwanaland reconstruction at $200 \mathrm{Ma}$ (Dalziel, 1992; Dalziel et al., 2000) showing the distribution of the Karoo and Ferrar continental flood basalt provinces and the Chon Aike Silicic LIP. Abbreviations: AP, Antarctic Peninsula; E, Ellsworth-Whitmore block; MBL, Marie Byrd Land; NZ, New Zealand; TI, Thurston Island. From Bryan \& Ernst (submitted).

C) Map of Mexico showing present configuration of plates, location of the Sierra Madre Occidental (SMO), distribution of Oligocene to Early Miocene rhyolitic volcanic rocks, and limits of area affected by Basin and Range extension (Henry \& Aranda-Gomez, 2000). Hatched area is the Trans-Mexican Volcanic Belt (TMVB), the current location of supra-subduction zone volcanism. Inset shows outcrops of Middle Tertiary rhyolite ignimbrite in Mexico and SW USA and extent of Basin and Range Province, both of which overlap in space and time. Modified from Ferrari et al. (2002) and Aguirre-Diaz \& Labarthe-Hernandez (2003).

D) Distribution map of the Late Carboniferous-Early Permian volcanic and intrusive units of the Kennedy-Connors-Auburn Silicic LIP and associated sedimentary basins. Abbreviations: LB, Lakefield Basin; ORB, Olive River Basin. 
Table 2 Comparison of the Whitsunday Silicic LIP with recent large-volume silicic volcanic provinces. Magma flux rate is averaged eruptive flux, based on known extrusive volumes for the provinces.

\begin{tabular}{llllll}
\hline Province & Age $(\mathrm{Ma})$ & $\begin{array}{l}\text { Volume } \\
\left(\mathrm{km}^{3}\right)\end{array}$ & $\begin{array}{l}\text { Dimensions } \\
(\mathrm{km})\end{array}$ & $\begin{array}{l}\text { Magma flux } \\
\left(\mathrm{km}^{3} \mathrm{kyr}^{-1}\right)\end{array}$ & References \\
\hline $\begin{array}{l}\text { Whitsunday } \\
\text { (Eastern Australia) }\end{array}$ & $\sim 132-95$ & $>2.2 \times 10^{6}$ & $>2500 \times 200$ & $>55$ & $\begin{array}{l}\text { Bryan et al. } \\
(1997 ; 2000)\end{array}$ \\
\hline $\begin{array}{l}\text { Altiplano-Puna } \\
\text { (central Andes) }\end{array}$ & $\sim 10-3$ & $>3 \times 10^{4}$ & $\sim 300 \times 200$ & $>4.3$ & De Silva (1989a, b) \\
\hline $\begin{array}{l}\text { Taupo Volcanic Zone } \\
\text { (New Zealand) }\end{array}$ & $1.6-0$ & $\sim 2 \times 10^{4}$ & $300 \times 60$ & $\sim 9.4-13$ & $\begin{array}{l}\text { Wilson et al. (1995); } \\
\text { Houghton et al. (1995) }\end{array}$ \\
\hline
\end{tabular}

the last ten years have extended the LIP record back to the Proterozoic and Archean, there are indications that Silicic LIP events may also have occurred in the Proterozoic. Probable Proterozoic examples of Silicic LIPs include the $\sim 750$ Ma Malani province of India (Sharma, 2004; 2005), which may have been part of a larger LIP cluster (Li et al., submitted), the $\sim 1590$ Ma Gawler Range-Hiltaba igneous province of central Australia (Fanning et al., 1988; Giles, 1988; Creaser \& White, 1991) and the Mid-Proterozoic Eastern ( 1500-1420 Ma) \& Western (1400-1340 Ma) Granite-Rhyolite provinces of North America (Kay et al., 1989).

The Whitsunday Silicic LIP (Bryan et al., 1997; 2000) is the largest of the world's Silicic LIPs (Figure 3A). A perspective on the scale and magnitude of the Whitsunday Silicic LIP is given in Table 2, which compares the province with the $\sim 1.6-0$ Ma Taupo Volcanic Zone (TVZ) of New Zealand. The TVZ is described as the largest and most frequently erupting silicic magmatic system on Earth where $~ 90 \%$ of erupted material is rhyolitic (Wilson et al., 1995; Sutton et al., 1995). Table 2 demonstrates that the Whitsunday Silicic LIP is orders of magnitude bigger than the TVZ in all aspects. Furthermore, the eruptive output of the Whitsunday Silicic LIP $\left(>2.2 \mathrm{Mkm}^{3}\right)$ is greater than that of several better-known continental flood basalt provinces. One of the unique features of this Silicic LIP in eastern Australia is the huge volume of coeval resedimented volcaniclastic rock $\left(>1.4 \mathrm{Mkm}^{3}\right)$ that accumulated in adjacent sedimentary basins (Figure 3A). The preserved areal extent of volcanism and its products is in excess of $3 \mathrm{Mkm}^{2}$. As new investigations are undertaken of the thinned continental fragments offshore from eastern Australia, further accumulations of rift-related volcaniclastic rocks are being identified (Exon et al., 2006) and expanding the tremendous eruptive output and preserved extent of this Silicic LIP. In contrast, the Chon Aike Silicic LIP is distinguished by being clearly, spatially and temporally related to flood basalt volcanism in the Karoo and Ferrar provinces (Figure 3B).

\section{Volcanic architecture}

The Sierra Madre Occidental province of western Mexico (Figure 3C) is the most recent and least deformed of the Silicic LIP examples, and is representative of the general architecture of Silicic LIPs.

The Sierra Madre Occidental is an extensive, relatively flatlying ignimbrite plateau extending for over $2000 \mathrm{~km}$ south from the U.S.-Mexico border, and is between 200 and $500 \mathrm{~km}$ wide, with an average thickness of $1 \mathrm{~km}$ (e.g., McDowell \& Clabaugh, 1979; Ferrari et al., 2002). More ancient and exhumed Silicic LIP examples occur as continental caldera systems and major batholiths, as represented by the $\sim 320-280$ Ma Kennedy-Connors-Auburn province of northeast Australia (Bain \& Draper, 1997; Bryan et al., 2003; Figure 3D). Extensive dyke swarms are exposed in the more deeply eroded provinces (e.g., Whitsunday, Kennedy-Connors-Auburn; Ewart et al., 1992; Stephenson et al., 1990; Figure 4). Diffuse dyke swarms ( $\geq 100 \mathrm{~km}$ wide) of mostly steeply-dipping dykes ranging from 1 to $50 \mathrm{~m}$ in width are characteristic, and the swarms can extend along strike for over $1000 \mathrm{~km}$ (Stephenson et al., 1990). General temporal trends in the dyke swarms are for silicic dykes to be cross-cut by mafic dykes (Allen, 2000; Bryan et al., 2000), which mirrors vertical compositional trends in the host volcanic stratigraphy. The more recently formed Silicic LIPs are expected to have similarly extensive mid to upper crustal granitic batholith underpinnings and dyke swarms, and more mafic igneous underplate at lower crustal depths (Ferrari et al., 2006).

The Silicic LIPs are the largest accumulations of primary volcaniclastic rocks, representing the entire range of fragmental products deposited directly by explosive and effusive eruption (White \& Houghton, 2006). Rhyolitic ignimbrite forms the overwhelming proportion of volcanic rock in all the Silicic LIPs, typically representing $>80 \%$ of the total stratigraphic thickness (Figure 5). Although rhyolite ignimbrite-dominated, the eruptive stratigraphy of a Silicic LIP can be considered as the 'negative image' of that of the continental flood basalt provinces (Figure 5). Both have a lower monotonous volcanic section $>1 \mathrm{~km}$ thick, being dominated by either flood basalts (continental flood basalt provinces) or rhyolite ignimbrites (Silicic LIPs), and both have an upper, $>1 \mathrm{~km}$ thick bimodal section where basalt and rhyolite are interbedded (Figure 5). Upper bimodal sections are well-expressed in the Yemen section of the Afro-Arabian flood basalt province (Ukstins Peate et al., 2005) and the Whitsunday Silicic LIP (Bryan et al., 2000).

Silicic LIP ignimbrites are predominantly dacitic to rhyolitic welded units that range from 10 's to a few 100 's $m$ in thickness (e.g., Bryan et al., 2000; Pankhurst et al., 1998; McDowell \& Clabaugh, 1979). Intracaldera facies ignimbrite units $\geq 1 \mathrm{~km}$ thick are also present and associated with coarse lithic lag breccias (e.g., Ewart et al., 1992; Bryan et al., 2000). However, the combination of burial, tilting and faulting, and exhumation have precluded mapping out the extents and estimating volumes of individual ignimbrite eruptive units in the Silicic LIPs, and even for the youngest and least deformed silicic LIP, $<10 \%$ of the Sierra Madre Occidental province has so far been mapped (Swanson \& McDowell, 2000). This remains an important area for future research to improve the database on large magnitude eruptions from these provinces (see also Mason et

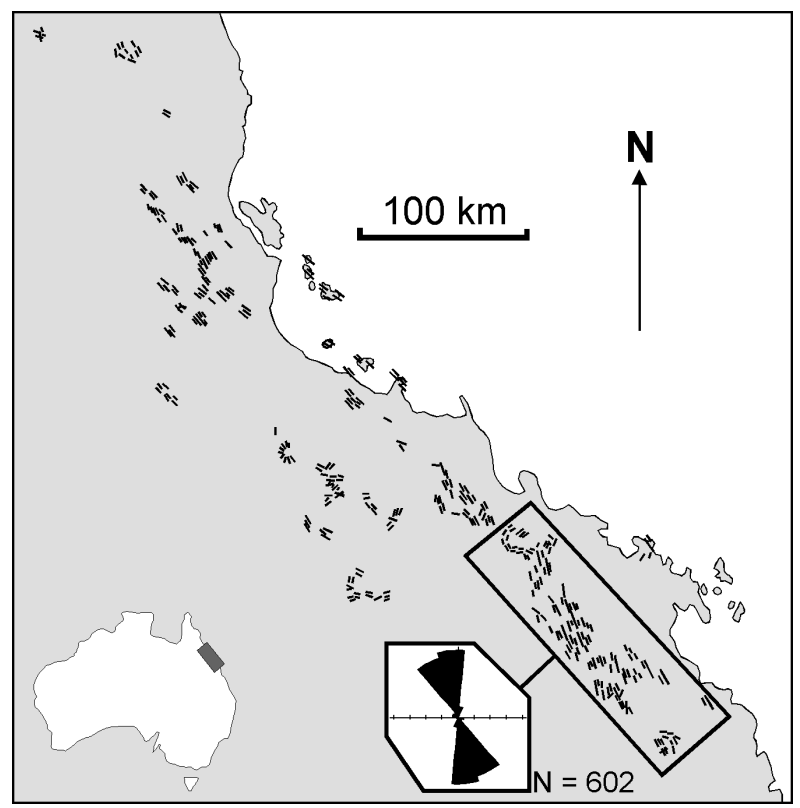

Figure 4 Dyke swarms through part of the Kennedy-ConnorsAuburn Silicic LIP of northeast Australia. Rose diagram of dyke trends refers to dykes in boxed area. Note the dominant NW trend to dykes along the length of the province. (Modified from Stephenson, 1990). 

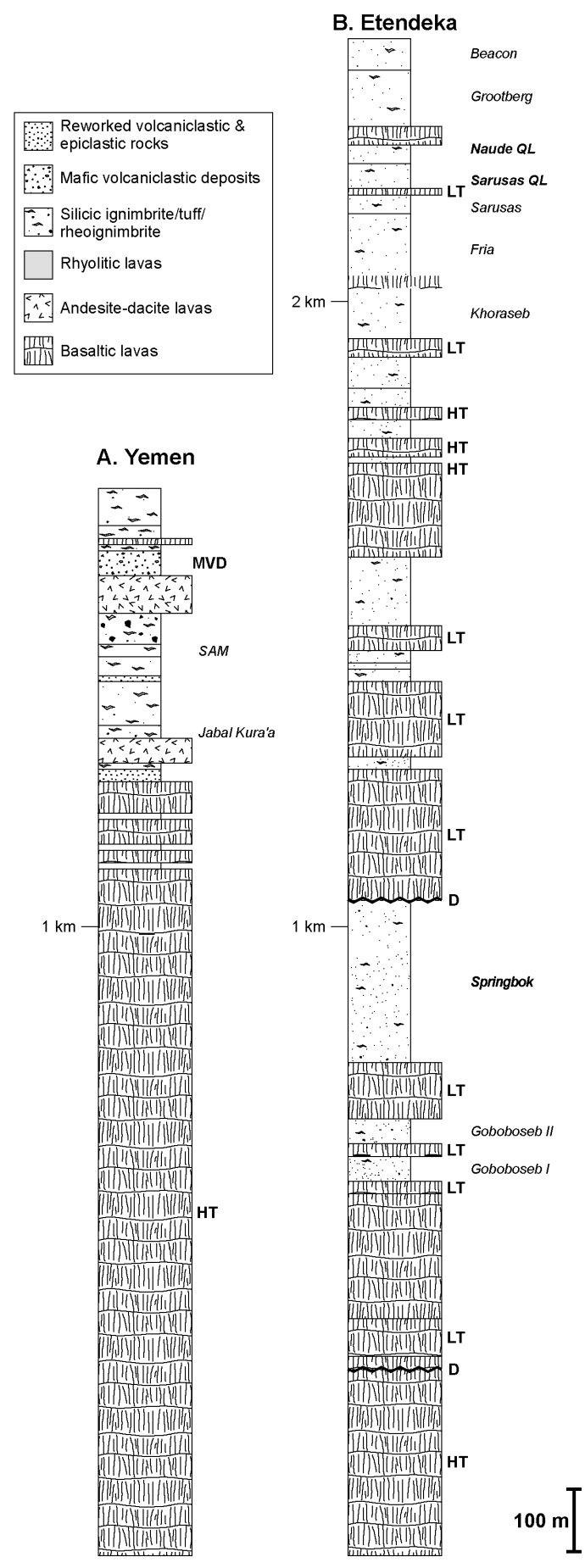

C. Whitsunday

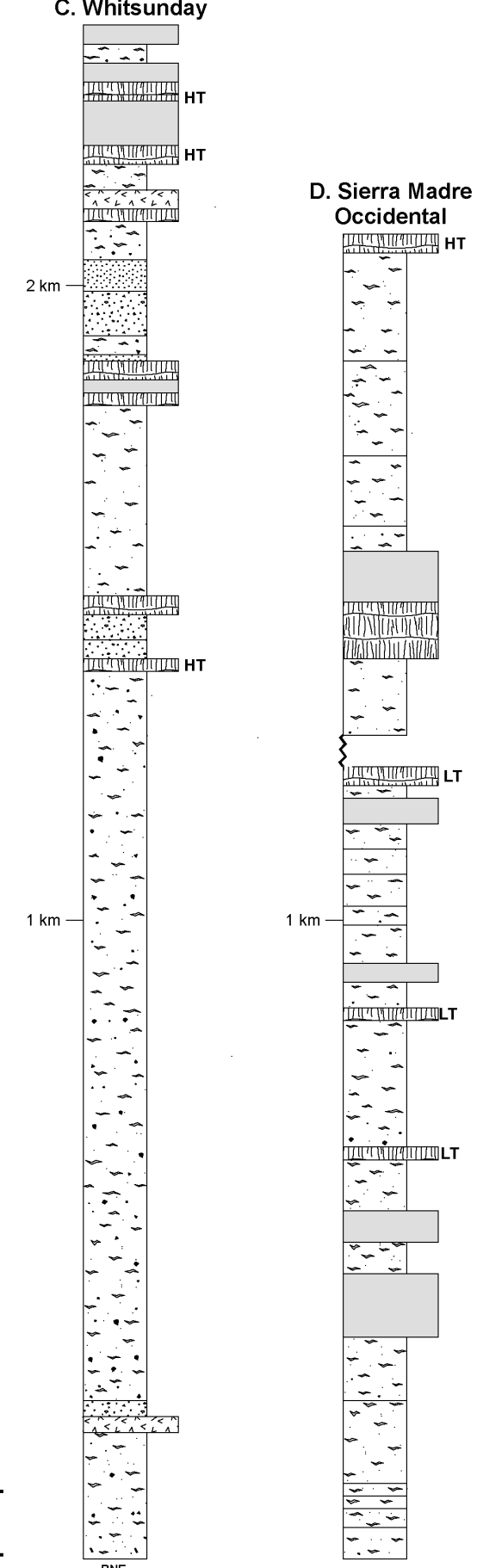

Figure 5 Generalised composite stratigraphic sections comparing two continental flood basalt provinces (Afro-Arabian and Etendeka) with two Silicic LIPs (Whitsunday and Sierra Madre Occidental). Dykes, sills and other intrusions are not shown.

A. Yemen section of the Tertiary Afro-Arabian continental flood basalt province, based on Baker et al. (1996) and Ukstins Peate et al. (2005).

B. Etendeka section of the Early Cretaceous Paraná-Etendeka continental flood basalt province, based on Marsh et al. (2001) and Ewart et al. (2004), with disconformities (D) known from the sequences distinguished. The major silicic eruptive units are labelled. The stratigraphic relationship between the northern Etendeka (Sarusas-Fria) and southern Etendeka (Grootberg, Beacon) quartz latites in the upper part of the section is an inferred extrapolation.

C. Early Cretaceous Whistunday Silicic LIP, based on Bryan et al. (2000), with the base to section not exposed (BNE).

D. Southern section of the Tertiary Sierra Madre Occidental Silicic LIP, based on Swanson et al. (1978); McDowell \& Clabaugh (1979 and references therein), with a regional time break shown for the section (Ferrari et al., 2002).

Lavas and volcaniclastic rocks are shown at arbitrary thicknesses on the x-axis to emphasise distinction in rock types. Discrete basalt types are distinguished where possible into high-Ti (HT) and low-Ti (LT) types. Several features of note are:

1) the basaltic lava-dominated and silicic ignimbrite-dominated character of the flood basalt provinces and Silicic LIPs, respectively;

2) the high-Ti basalts are common at the base of the flood basalt sequences, but are interbedded with low-Ti basalts;

3) basaltic lavas, including higher-Ti types occur in the upper parts of the Silicic LIPs; and

4) the upper sections for the flood basalt provinces and Silicic LIPs are compositionally bimodal, and result from an increasing abundance up sequence of silicic pyroclastic rocks in the flood basalt provinces, and mafic lavas in the Silicic LIPs. 
al., 2004). Some insight into the magnitude of large volume eruptions from the Silicic LIPs is given by the Fish Canyon Tuff, which is one of the largest silicic pyroclastic eruptions known at $>4500$ $\mathrm{km}^{3}$ DRE (dense rock equivalent; Mason et al., 2004), and was erupted at the same time and along strike to the north of the Sierra Madre Occidental Silicic LIP. Recent investigations into the northern core of the Sierra Madre Occidental are drawing many parallels with the San Juan Volcanic Field in terms of abundances of ignimbrites and calderas (Swanson et al., 2006). Consequently, it is reasonable to expect, given the huge total eruptive volumes, that Silicic LIP events comprised many large explosive eruptions (eruption magnitude $M>8$ or DRE volumes of $>400 \mathrm{~km}^{3}$; Pyle, 2000), which may also have occurred at a greater frequency than indicated from the known database of large explosive eruptions (Mason et al., 2004).

In detail, ignimbrites from each province show considerable variety in deposit features. Ignimbrites vary from being non-welded to densely welded, but in contrast to the continental flood basalt provinces, rheomorphic ignimbrites are rare. This general absence is reflected by their lower eruptive temperatures $\left(750-900{ }^{\circ} \mathrm{C}\right.$; Ewart et al., 1992; Cameron et al., 1980b; Wark, 1991), the common presence of hydrous mineral phases (biotite, amphibole), and crustal setting of magmatism (Bryan et al., 2002). The ignimbrites show considerable variation in lithic content, but most contain a lithic-rich basal concentration layer, and multiple intra-ignimbrite lithic concentration zones are common in the thicker units. In general, the Whitsunday ignimbrites appear to be relatively more lithicrich (Ewart et al., 1992; Bryan et al., 2000) than those from the other Silicic LIPs.

\section{Eruptive sources}

Caldera-type complexes are the primary eruptive sources producing the extensive ignimbrite fields of the Silicic LIPs, but are part of a larger multiple vent volcanic system that includes numerous extracaldera (and intracaldera) effusive vents for basaltic and silicic magmas (e.g., Bryan et al., 2000; 2002). Evidence for calderas as source vents for the large volume ignimbrites includes coarse lithic lag breccias and megabreccias within the ignimbrite eruptive units, and ponding relationships (e.g., Ewart et al., 1992; Bryan et al., 2000; Swanson \& McDowell, 1984; Swanson et al., 2006). Caldera dimensions appear to range between 10 to $30 \mathrm{~km}$ in diameter, whereas calderas with 30 to $40 \mathrm{~km}$ and possibly up to $100 \mathrm{~km}$ diameters have been inferred for the Chon Aike Province (Aragón et al., 1996; Riley et al., 2001). Many cauldrons are wellexposed in the more deeply dissected Permo-Carboniferous Kennedy Province of northeastern Australia, which exhibit a variety of geometries and composite arrangements; with individual cauldrons ranging from 10 to $40 \mathrm{~km}$ in diameter (Bain \& Draper, 1997).

The great thicknesses and extents of welded silicic pyroclastic rocks are probably the result of eruptions from many calderas, in places overlapping, along the length of the Silicic LIP belt. Few calderas, however, have been identified within the Silicic LIPs, primarily because of the scale and huge volumes of volcanic material erupted over a relatively short duration and the consequent burial of vent sites, and overprinting tectonic deformation and erosion (Bryan et al., 2002). The lack of caldera recognition in the Sierra Madre Occidental has been mentioned widely in the literature (McDowell \& Clabaugh, 1979; Swanson \& McDowell, 1984; Aguirre Diaz \& Labarthe Hernández, 2003; Swanson et al., 2006), where fewer than 20 calderas have been recognised. The problem of caldera recognition is even more extreme for the Whitsunday Silicic LIP where only 4-5 caldera-type complexes or eruptive centres for the ignimbrites have so far been identified (Ewart et al., 1992; Bryan et al., 2000) for a province with an extrusive output of $>2.2 \mathrm{Mkm}^{3}$

Where silicic eruptions were concurrent in areas of active extensional tectonics, ignimbrite-forming eruptions also occurred from extensive volcano-tectonic fissures producing welded pyro- clastic dykes. Welded pyroclastic dykes occur in the Whitsunday (Bryan et al., 2000); Sierra Madre Occidental (Aguirre Diaz \& Labarthe Hernández, 2003) and Chon Aike (Pankhurst et al., 1998) Silicic LIPs. In the Sierra Madre Occidental, the welded pyroclastic dykes or fissures, which are up to several kilometres in length, appear restricted to the Early Miocene ignimbrite pulse in the southern part of the province, which was being dissected by regional Basin and Range extensional graben-bounding faults (Ferrari et al., 2002; Aguirre Diaz \& Labarthe Hernández, 2003). The central core of the province remains unextended, however, and therefore caldera complexes are expected to be the dominant eruptive sites in these regions (see also Swanson et al., 2006).

\section{Petrology and geochemistry}

Most Silicic LIP ignimbrites contain the phenocryst assemblage of plagioclase, quartz, and $\mathrm{Fe}-\mathrm{Ti}$ oxides with uncommon alkali feldspar, and the ferromagnesian phases dominated by pyroxene, biotite and/or hornblende (Cameron et al., 1980; Wark, 1991; Ewart et al., 1992; Riley et al., 2001). Although the ignimbrite phenocryst assemblages resemble "orogenic" silicic volcanics, they tend to contain less hornblende and biotite, and ignimbrites from the Whitsunday and Sierra Madre Occidental Silicic LIPs are predominantly pyroxene rhyolites (Ewart et al., 1992; Cameron et al., 1980). The ignimbrites display considerable variation in crystal content with crystal-poor $(<10 \%)$ and -rich (up to $50 \%)$ types present in each province. In contrast, the rhyolites present in the continental flood basalt provinces are predominantly crystal-poor $(<20 \%)$ and hydrous phenocryst phases are usually absent (e.g., Cleverly et al., 1984; Ewart et al., 1998; Preston et al., 1998; Ukstins Peate et al., 2005).

Silicic LIPs show a broad spectrum of compositions from basalt to high-silica rhyolite (Figure 5), in contrast to the bimodality of igneous compositions observed in continental flood basalt provinces (e.g., Marsh et al., 2001; Ukstins Peate et al., 2005). The volcanic rocks typically show calc-alkaline affinities that resemble modern destructive plate margin volcanic rocks rather than bimodal or alkalic volcanism associated with continental flood basalt provinces and continental rifts. The calc-alkaline chemistry of the rhyolites has caused ambiguity when interpreting the tectonic setting of magmatism, and as a consequence, the tectonic setting of Silicic LIP magmatism has been wrongly interpreted in the past.

In detail, igneous compositions are volumetrically silicic-dominant ( $>65 \mathrm{wt} \% \mathrm{SiO}_{2}$ ), reflecting the ubiquitous nature of rhyolitic ignimbrite, lava, dyke and granitic lithologies. Ignimbrite compositions vary from dacitic to rhyolitic $\left(\sim 68-77 \mathrm{wt} \% \mathrm{SiO}_{2}\right)$, and are generally more silicic and less Fe-rich than silicic ignimbrites of the continental flood basalt provinces (cf. Ewart et al., 1998, 2004; Ukstins Peate et al., 2005). Lavas in the Silicic LIPs typically are bimodal (basalt-basaltic andesite and rhyolite), whereas for the Whitsunday and Kennedy-Connors-Auburn provinces, it is the dykes that exhibit a more continuous range from basalt through to rhyolite (Ewart et al., 1992; Bryan et al., 2000; Allen, 2000). The basaltic compositions tend to show more compositional variation as evidenced in their minor and trace element contents, reflecting the presence of low-Ti $(\leq 1 \mathrm{wt} \%)$ and high-Ti $(>2 \mathrm{wt} \%)$ basaltic magma types (Figure 6). Both the rhyolites and basalts have geochemical signatures transitional between within-plate and convergent margin fields on trace element discrimination diagrams (Figure 7). Geochemical studies for the Whitsunday and Chon Aike provinces have demonstrated that the subduction-related chemistry of the magmas was inherited from the crustal source (Ewart et al., 1992; Riley et al., 2001). Several studies have demonstrated the relatively primitive initial isotopic compositions of rhyolites from the Silicic LIPs with initial ${ }^{87} \mathrm{Sr} /{ }^{86} \mathrm{Sr}$ ratios generally $<0.71$ and eNd values between +4 and -4 , implying mantle and/or newly accreted crustal magma sources (e.g., Lanphere et al., 1980; Ewart et al., 1992; Riley et al., 2001; Ferrari et al., 2006). The combined geochemical and isotopic data therefore indicate the importance of relatively young, nonradiogenic calc-alkaline crust in rhyolite petrogenesis. 

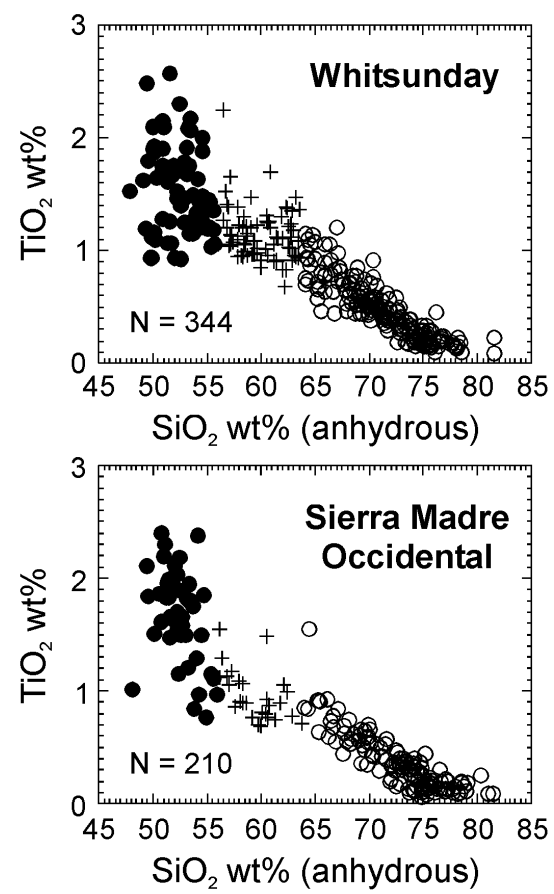

Figure $6 \mathrm{TiO}_{2}-\mathrm{SiO}_{2}$ relationships for igneous rocks of the Whitsunday and Sierra Madre Occidental Silicic LIPs. Filled circles are for basalt-basaltic andesite compositions (<56 wt\% $\left.\mathrm{SiO}_{2}\right)$; crosses are andesites (56-64 wt\% $\left.\mathrm{SiO}_{2}\right)$; and circles are dacites-rhyolites (>64 wt\% SiO2). Note the variation in $\mathrm{TiO}_{2}$ contents for the mafic rocks, reflecting the presence of low-Ti $\left(\leq 1 \mathrm{wt} \% \mathrm{TiO}_{2}\right)$ and high-Ti $\left(\geq 2 w t \% \mathrm{TiO}_{2}\right)$ lava types. $\mathrm{N}$ is number of analyses.

\section{Rhyolite petrogenesis}

Although rhyolites can occur in a variety of tectonic settings, large volume silicic magmatism $\left(>10^{4} \mathrm{~km}^{3}\right)$ is characteristic of continental regions undergoing extension (e.g., western U.S.A.), volcanic arcs undergoing rifting to form a backarc basin (e.g., Taupo Volcanic Zone, New Zealand), or the formation of volcanic rifted margins (Bryan et al., 1997; 2002). The Silicic LIPs record the largest rhyolite magma-generating events in Earth history, and the volume of silicic magma generated and erupted appears to be at least an order of magnitude larger than that observed in other regions (Table 2). Rhyolite petrogenesis is therefore an important issue in understanding if the Silicic LIPs similarly represent important crustal growth events in response to new magmatic additions from the upper mantle as observed for the other LIPs.

The generation of the large volumes of silicic magma in the Silicic LIPs ultimately reflects large-scale crustal melting processes. Large degrees of crustal partial melting will be controlled by the water content and composition of the crust, and a large ( \pm mass) thermal input from the mantle. Partial melting of hydrated, calc-alkaline and high-K calc-alkaline andesite/basaltic andesite or amphibolitic crust (e.g., Roberts \& Clemens, 1993) seems critical in generating the large volumes of predominantly I-type silicic igneous melt (Bryan et al., 2002).

Crustal setting is a key feature in explaining the dominantly silicic nature of Silicic LIP events. The Phanerozoic examples of Silicic LIPs (Table 1) have formed along long-lived paleo- and active continental margins characterised by a relatively young fertile, hydrous lower crust. Basement to the Whitsunday Volcanic and Chon Aike provinces, and in large part the Sierra Madre Occidental, comprises Palaeozoic-Mesozoic igneous and sedimentary rocks accreted and/or deposited along the continental margin. These crustal materials have been generated by subduction up to 100's Myrs prior to the emplacement of the Silicic LIP and subduction-generated igneous rocks may reside as underplate or as widespread intrusions in the lower crust.

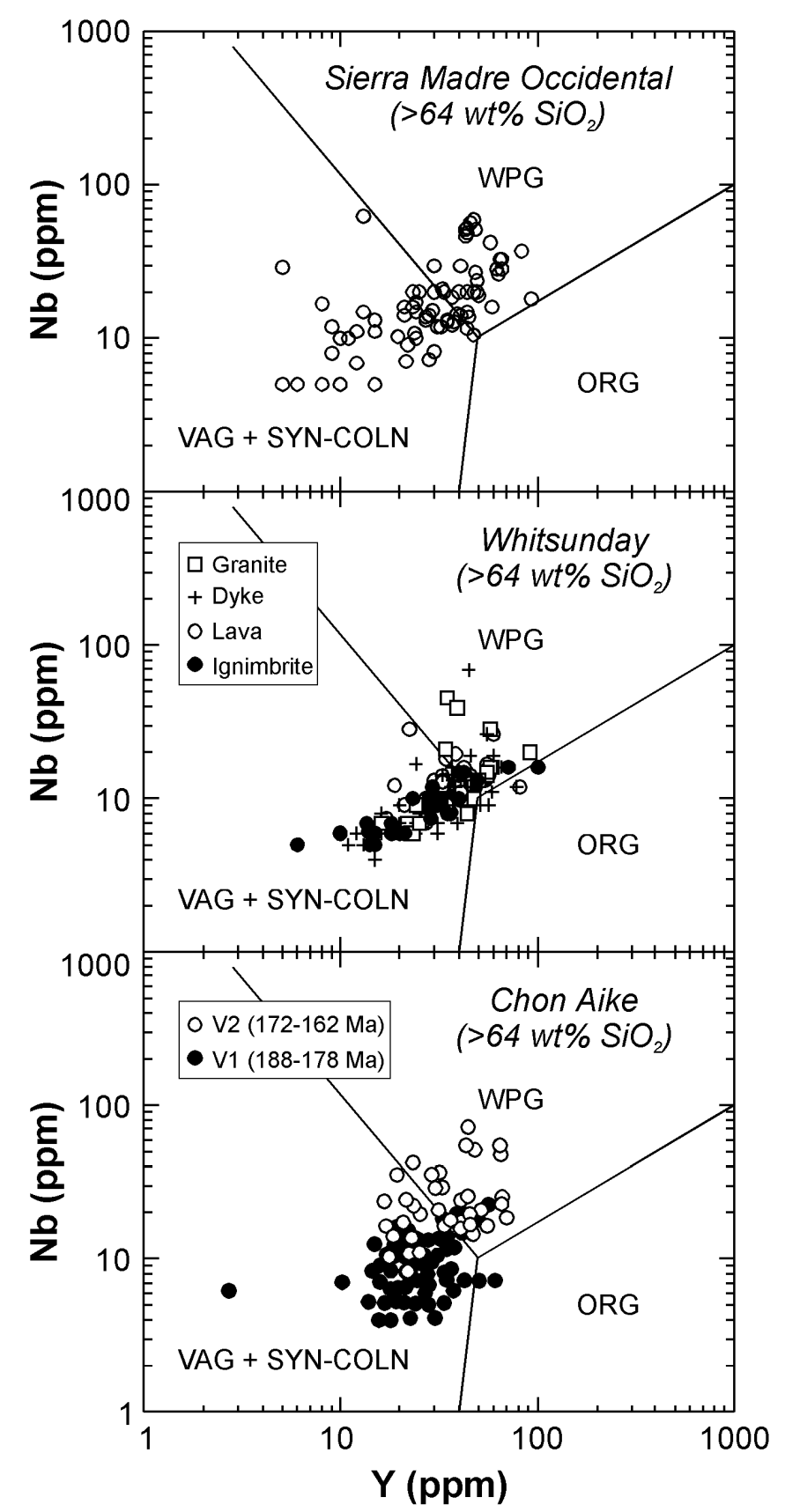

Figure $7 \mathrm{Nb}-\mathrm{Y}$ discrimination plots (Pearce et al., 1984) for the silicic rocks from the Whitsunday, Sierra Madre Occidental and Chon Aike Silicic LIPs showing the characteristic transitional signatures from within-plate to convergent margin fields. Abbreviations: WPG, Within-plate granites; ORG, Ocean ridge granites; and VAG+SYN-COLL, Volcanic arc and syn-collisional granites. Data for the Chon Aike Silicic LIP from Riley et al. (2001), with compositions from the two pulses of volcanic activity (V1 and V2) distinguished.

Remelting of these crustal materials is therefore likely to have been important in producing the geochemical and relatively unradiogenic isotopic signatures of the Silicic LIP rhyolites. The involvement of Mesozoic to Palaeozoic crust in magma genesis is supported by $\mathrm{Nd}$ model $\mathrm{T}_{\mathrm{DM}}$ ages for the Whitsunday Volcanic Province (mostly 250-600 Ma; Ewart et al., 1992), whereas mid-late Proterozoic ("Grenvillian") model ages in the eastern (interior) part of the Chon Aike Province reflect either that of the sedimentary provenance or the formation of the crust (Pankhurst \& Rapela, 1995; Pankhurst et al., 1998; Riley et al., 2001). For the Sierra Madre Occidental, recent 
U-Pb zircon dating has identified Mesozoic to Middle Tertiary age xenocrystic zircons in the ignimbrites, which records the involvement of young and isotopically primitive, subduction-related igneous basement in rhyolite magma generation (Bryan et al., submitted). In contrast, the Phanerozoic continental flood basalt provinces have been emplaced onto Archaean cratons or along the edges of cratons, where the crust is older, drier and more refractory such that any lower crustal melting would occur only at very high temperatures. Giant mafic dyke swarms (e.g., Baragar et al., 1996; Yale \& Carpenter, 1998) imply a brittle crust in cratonic regions permitting deep-penetrating structures to channel mafic melt to the surface. In the cases of continental flood basalt provinces that have significant volumes of silicic volcanism, it is the sustained thermal and material input of mafic magma that results in crustal melting and assimilation (Bryan et al., 2002). The Paraná-Etendeka rhyolites, for example, are anhydrous and had an eruption temperature in excess of $1050^{\circ} \mathrm{C}$ (Harris \& Milner, 1997), consistent with partial melting and assimilation of anhydrous crustal material at very high temperatures.

\section{Environmental impacts of Silicic LIP magmatism}

The close correspondence between the age of several LIP events and mass extinctions has provided a compelling linkage between the two (Wignall, 2005). Considerable focus has been on determining the extinction mechanism of LIP eruptions, and climatic impact of LIP magmatism is generally attributed to the eruption of enormous volumes of basaltic magma and the release of volatiles such as $\mathrm{CO}_{2}, \mathrm{~S}, \mathrm{Cl}$ and $\mathrm{F}$ (Robock, 2000; Frey et al., 2000; Wignall, 2001; 2005). However, it is unclear whether the $\mathrm{CO}_{2}$ fluxes are sufficient on their own to cause the environmental changes (Wignall, 2005; Self et al., 2005). In contrast, $\mathrm{SO}_{2}$ emissions and sulphate aerosol loading of the atmosphere following flood basalt eruptions may have been sufficiently large to cause atmospheric cooling for up to a decade or longer (Self et al., 2005), acid rain, acidification and soil nutrient leaching (Killan et al., 2006). The potential environmental impact from associated large volume silicic eruptions during LIP events, however, has received little attention. This is in part because either the total volume of silicic volcanic rocks, or the magnitude of constituent silicic eruptions, remains poorly constrained.

Volcanic eruptions can affect the climate system on many timescales (Robock, 2000). Widespread climatic impacts from volcanic eruptions require the injection of aerosols and ash emitted by the eruptions to high atmospheric levels (i.e. stratosphere), particularly at low latitudes for global dispersion. The greatest effects on climate and atmospheric chemistry are achieved when sulphuric acid aerosol particles are injected into the stratosphere following volcanic eruptions where they have a longer residence time and greater global dispersal than if the $\mathrm{SO}_{2}$ remained in the troposphere (McCormick et al., 1995; Frey et al., 2000; Robock, 2000; Wallace, 2001). Significant climatic effects may also result from the cumulative effects of eruptions emitting large volumes of $\mathrm{CO}_{2}$, which has a longer residence time in the atmosphere (Wallace, 2001). The eruptions that feed flood basalt lava fields have generally low eruption heights $(\leq 5 \mathrm{~km})$, long durations (years to 10's years), and effusion rates approaching the largest witnessed basaltic eruptions (Self et al., 1997); they therefore lack the eruptive mechanisms to inject huge volumes of ash and aerosols quickly into the stratosphere, even if they are associated with large $\mathrm{SO}_{2}$ emissions (Self et al., 2005).

The volumetrically most important volcanic activity of continental flood basalt provinces consists of largely non-explosive eruption of flood basalts from fissures (Wignall, 2001). Volatile release during most non-explosive basaltic eruptions will therefore remain in the troposphere, such as the sulphuric aerosol cloud or dry fog that persisted over much of Europe and North Atlantic following the 1873-4 Laki eruption in Iceland (see Thordarson \& Self, 2003 for review; Grattan, 2005). Basaltic eruption plumes may be able to inject $\mathrm{SO}_{2}$ and other aerosols into the stratosphere at high latitudes where the tropopause boundary is lower (Stothers et al., 1986). However, large-scale subsidence through the stratosphere dominates at high latitudes (e.g., Holton et al., 1995), preventing interhemispheric circulation and effectively limiting aerosol and ash dispersion to the high latitudes and troposphere. It is worth noting that the Siberian Traps, Karoo-Ferrar-Chon Aike and North Atlantic LIPs were emplaced at high latitudes $\left(\geq 60^{\circ}\right)$. In summary, for flood basalt eruptions, it may be the intensity and persistence of eruption rather than eruption volume or the requirement for explosive eruption mechanisms that are the critical factors for any climate forcing (Jolley \& Widdowson, 2005).

Alternatively, the greatest atmospheric impacts may result from closely-spaced and repeated, large-volume mafic and silicic eruptions that inject large tonnages of aerosols and ash at tropospheric and stratospheric levels, respectively. It is the silicic eruptions during LIP events that had the magma volume $\left(>1000 \mathrm{~km}^{3}\right)$ and eruptive mechanisms (i.e., stratosphere-penetrating sub-Plinian to Plinian eruption columns) to inject ash and aerosols at high atmospheric levels for global dispersion. As several recent studies have demonstrated, silicic volcanic rocks represent a significant fraction of the volcanic deposits erupted during the main pulse, and particularly during the peak and final stages of flood volcanism (Peate, 1997; Frey et al., 2000; Marsh et al., 2001; Ukstins Peate et al., 2005). No studies have yet been undertaken to estimate the potential volatile emissions from the large silicic eruptions of the continental flood basalt provinces and Silicic LIPs.

The potential for substantial atmospheric effects by large silicic eruptions from LIPs is indicated by satellite measurements of $\mathrm{SO}_{2}$ releases during several recent subduction-related andesitedacite explosive eruptions. The $\mathrm{SO}_{2}$ releases were one to two orders of magnitude greater than petrologic estimates of the dissolved $\mathrm{S}$ abundances in the erupted magma volume (e.g., Westrich \& Gerlach, 1992; Sharma et al., 2004). This discrepancy is due to the existence of a separate gas phase before eruption (Wallace, 2001). Recent intraplate basaltic eruptions (which are small-scale modern analogues to the flood basalt eruptions), however, do not appear to possess this 'excess sulphur' mass (Sharma et al., 2004). Consequently, estimating aerosol masses emitted during ancient silicic eruptions remains extremely problematic, and likely to be underestimated.

An important implication then for potential atmospheric effects is that large explosive eruptions of silicic magma from LIPs can release large amounts of $\mathrm{SO}_{2}$ (and other aerosols) occuring as a separate gas phase prior to eruption. This is despite the fact that in general, silicic magmas have very low concentrations of dissolved $\mathrm{S}$. Underlying basaltic magma saturated with $\mathrm{H}_{2} \mathrm{O}-\mathrm{CO}_{2}-\mathrm{S}$ gas is considered the major source for the $\mathrm{SO}_{2}$ occurring as an exsolved gas phase to the silicic magma, and several petrologic studies have confirmed a magmatic origin for sulphur (Hattori, 1993; Pallister et al., 1996; Wallace, 2001; Bryan, 2006). Recent studies have also stressed the importance of basaltic magmatism in rejuvenating and remobilising batholithic volumes of silicic magma (Bachmann et al., 2002; Bachmann \& Bergantz, 2003). In particular, it was the transfer of $\mathrm{H}_{2} \mathrm{O}-\mathrm{F}-\mathrm{S}-\mathrm{Cl}$ fluids or 'gas sparging' from underlying basaltic magma that was the driving force in reheating a $>5000 \mathrm{~km}^{3}$ body of silicic crystal mush, and potentially leading to the eruption of the voluminous Fish Canyon Tuff (Bachmann et al., 2002). Critically, there may be little recorded evidence in the phenocrysts of this process and the existence of a substantial volume of a co-existing exsolved gas phase such that petrological methods (e.g., Devine et al., 1984) may significantly underestimate the volume of $\mathrm{SO}_{2}$ released during the eruptions. For the silicic eruptions from the flood basalt provinces, the evolution by assimilation-fractional crystallisation processes from temporally-related flood basalt magmas (e.g., Ewart et al., 2004) raises the possibility that gas fluxing from the basaltic magmas may have been an important factor in promoting an explosive eruptive style, large $\mathrm{SO}_{2}$ emissions, and therefore climatic impact. 


\section{Mineralisation associated with Silicic LIPs}

Magmatic Ni-Cu-PGE mineralisation associated with ultramafic-mafic layered intrusions of continental flood basalt provinces (e.g., Lightfoot \& Hawkesworth, 1997) is generally recognised as the dominant mineralisation style in LIPs. However, because LIP events record the emplacement of tremendous volumes of magma throughout the crustal profile, considerable scope exists for the generation of giant hydrothermal systems powered by the thermal energy linked to the crustal emplacement of magmas (Pirajno, 2006; this issue). Some of the most economically significant epithermal $\mathrm{Au}-\mathrm{Ag}$ fields (low-sulphidation-type) are associated with Silicic LIPs, with the Sierra Madre Occidental (e.g., Staude \& Barton, 2001; Camprubí et al., 2003), Chon Aike (Schalamuk et al., 1997) and Kennedy-Connors-Auburn provinces (Bain \& Draper, 1997; Perkins \& Kennedy, 1998) being the most actively explored and mined. In addition to low-sulphidation epithermal mineralisation, higher sulphidation and porphyry-related $\mathrm{Cu}-\mathrm{Au}$ (e.g., Sierra Madre Occidental, Staude \& Barton, 2001; Whitsunday, Clarke et al., 1971; Kennedy-Connors-Auburn, Orr, 1994), and rarely, volcanic hosted massive sulphide mineralisation (Kennedy-Connors-Auburn, Zhaw et. al., 2003) styles also occur.

Extensive epithermal $\mathrm{Au}-\mathrm{Ag}$ fields can be developed within the Silicic LIPs. As an example, more than 800 epithermal precious metal occurrences are known from the Sierra Madre Occidental occurring in an area $>0.5 \mathrm{Mkm}^{2}$ (Staude \& Barton, 2001; Camprubí et al., 2003). Epithermal mineralisation may be more intensive forming economically important districts up to $500 \mathrm{~km}^{2}$ (e.g., Cerro Vanguardia district in the Chon Aike province; Schalamuk et al., 1997). A common feature of the Silicic LIPs is that epithermal mineralisation generally has younger ages than the associated silicic volcanism, forming at the end of the main period or pulses of silicic magmatism (Table 3). This may indicate that large mineralising hydrothermal systems were only established and maintained towards the end of the large volume magmatic pulses, when magmatic input and heat flow into the mid and upper crust had reached its greatest intensity.

Epithermal mineralisation within Silicic LIPs appears to be localised in two structural settings: 1) along volcanic-collapse structures and arcuate caldera-bounding faults; and 2) along major graben-bounding extensional faults. Many continental calderas are sited at the intersection of lineaments or fault structures, so an overriding tectonic control to the location of mineralisation cannot be ruled out in mineralised caldera settings. In the Sierra Madre Occidental, an Early Miocene ( 24-20 Ma) pulse of ignimbrite activity occurred in the southern part of the province, and was spatially and temporally associated with graben development and basin-and-range-style extension of the province (Ferrari et al., 2002). Many Early Miocene epithermal deposits occur within and along the margins of the grabens (e.g., Bolaños, San Martin de Bolaños-La Yesca). In addition, it has recently been recognised that some of the regional fault structures were also conduits for the silicic magmas resulting in fissural styles of eruption for the ignimbrites (Aguirre-Diaz \& Labarthe-Hernandez, 2003). Consequently, there is strong evidence to indicate that the major extensional structures within the Silicic LIPs were acting as pathways for mafic to silicic magmas, as well as for mineralising hydrothermal fluids.

\section{Conclusions}

Silicic Large Igneous Provinces are an important, albeit less common expression of LIP events along continental margins. These provinces bear all the hallmarks we usually associate with LIP events, in particular, large erupted volumes $\left(>0.1 \mathrm{Mkm}^{3}\right)$ and areal extents $\left(>0.1 \mathrm{Mkm}^{2}\right)$, high magma emplacement rates (or evidence for a transient high-emplacement rate pulse or pulses), and intraplate geochemical signatures and setting. The two Mesozoic examples (Chon Aike and Whitsunday) form LIP clusters, temporally overlapping with other LIP events, and were related to continental breakup. For the Chon Aike Silicic LIP, the initiation of crustal partial melting and rhyolite magma generation has been interpreted to be in response to crustal heating and magmatic underplating related to the emplacement of the neighbouring Karoo-Ferrar continental flood basalt provinces (Riley et al., 2001). Consequently, as for other LIPs, the driving processes of large volume melt extraction from the upper mantle and large mantle-derived thermal and material fluxes into the crust (driving widespread partial melting of the crust) are considered fundamental to the generation of Silicic LIPs. The Silicic LIPs were an important source of ash and aerosol contributions to the atmosphere, but it remains unclear if LIP clusters comprising Silicic LIPs and continental flood basalt provinces or oceanic plateaus had an increased environmental impact. Silicic LIPs are important hosts to precious metal mineralisation, forming globally important Au-Ag metal provinces.

\section{Acknowledgements}

Steve Sherwood, Pierre-Simon Ross and Tony Ewart are thanked for discussions on aspects of this manuscript. Rod Holcombe is thanked for assistance in preparing Figure 3D. Martin Valencia Moreno is thanked for providing geochemical data for the Sierra Madre Occidental province. Yigang $\mathrm{Xu}$ is thanked for the opportunity to contribute this paper to the Episodes volume on Large Igneous Provinces. Ingrid Ukstins Peate is thanked for providing a constructive and supportive review of the manuscript.
Table 3 Summary of ages of magmatism and mineralisation for several Silicic LIPs. Data sources: Bryan \& Ernst (submitted, and references therein): Perkins \& Kennedy (1998); Schalamuk et al. (1997); Camprube et al, (2003); Clarke et al. (1971).

\begin{tabular}{|c|c|c|c|c|c|}
\hline Silicic LIP & Location & $\begin{array}{l}\text { Age range of } \\
\text { Magmatism } \\
(\mathrm{Ma})\end{array}$ & $\begin{array}{l}\text { Age of } \\
\text { igneous } \\
\text { pulses (Ma) }\end{array}$ & $\begin{array}{l}\text { Age range of } \\
\text { Mineralisation } \\
\text { (Ma) }\end{array}$ & $\begin{array}{l}\text { Mineral deposit } \\
\text { examples }\end{array}$ \\
\hline $\begin{array}{l}\text { Sierra Madre } \\
\text { Occidental }\end{array}$ & Western Mexico & $\sim 38-20$ & $32-28,24-20$ & $36-27 ; 23-18$ & $\begin{array}{l}\text { Guanajuato, La } \\
\text { Guitarra }\end{array}$ \\
\hline Chon Aike & $\begin{array}{l}\text { South America- } \\
\text { Antarctica }\end{array}$ & $188-153$ & $\begin{array}{l}188-178,172- \\
162,157-153\end{array}$ & $\sim 153-138$ & $\begin{array}{l}\text { Cerro } \\
\text { Vanguardia }\end{array}$ \\
\hline $\begin{array}{l}\text { Kennedy- } \\
\text { Connors-Auburn }\end{array}$ & Eastern Australia & $\sim 320-280$ & & $\sim 300-290$ & $\begin{array}{l}\text { Cracow, Mt } \\
\text { Leyshon }\end{array}$ \\
\hline Whitsunday & Eastern Australia & $132-95$ & $\begin{array}{l}\text { 118-113; } \\
110-105\end{array}$ & $108-98$ & $\begin{array}{l}\text { Pentecost } \\
\text { Island }\end{array}$ \\
\hline
\end{tabular}

\section{References}

Aguirre-Diaz, G.J., and Labarthe-Hernandez, G., 2003, Fissure ignimbrites; fissure-source origin for voluminous ignimbrites of the Sierra Madre Occidental and its relationship with basin and range faulting: Geology, v. 31, pp. 773-776.

Allen, C.M.,2000, Evolution of a post-batholith dike swarm in central coastal Queensland,Australia: arc-front or back-arc?: Lithos, v. 51, pp. 331-349

Aragón, E., Rodriguez, A.M.I., and Benialgo, A. 1996, A calderas field at the Marifil Formation, new volcanogenic interpretation, Norpatagonian Massif, Argentina: Journal of South American Earth Sciences, V. 9, pp. 321-328.

Bachmann, O., and Bergantz, G.W., 2003, Rejuvenation of the Fish Canyon magma body: A window into the evolution of large-volume silicic magma systems: Geology, v. 31, pp. 789-792. 
Bachmann O., Dungan M.A., and Lipman, P.W., 2002, The Fish Canyon magma body, San Juan volcanic field, Colorado; rejuvenation and eruption of an upper-crustal batholith: Journal of Petrology, v. 43, no. 8, pp. 1469-1503.

Bain J.H.C., Draper J.J., eds, 1997, North Queensland Geology: Queensland Geology, v. 9, 600 pp.

Baker, J., Snee, L., and Menzies, M., 1996, A brief Oligocene period of flood volcanism in Yemen: implications for the duration and rate of continental flood volcanism at the Afro-Arabian triple junction: Earth and Planetary Science Letters, v. 138, pp. 39-55.

Baragar, R.A., Ernst, R.E., Hulbert, L., and Peterson, T., 1996, Longitudinal Petrochemical Variation in the Mackenzie Dyke Swarm, Northwestern Canadian Shield: Journal of Petrology v. 37, pp. 317 359

Blake, T.S., Buick, R., Brown, S.J.A., and Barley, M.E., 2004, Geochronology of a Late Archaean flood basalt province in the Pilbara Craton, Australia: constraints on basin evolution, volcanic and sedimentary accumulation, and continental drift rates: Precambrian Research, v. 133, pp.143-173.

Bryan, S.E., 2005, The Early Cretaceous Whitsunday Silicic Large Igneous Province of eastern Australia: Http://www.largeigneousprovinces.org/ 05aug.html

Bryan, S.E., 2006, Petrology and geochemistry of the Quaternary calderaforming, phonolitic Granadilla eruption, Tenerife (Canary Islands): Journal of Petrology, v. 47, no. 8, pp. 1557-1589.

Bryan, S.E., and Ernst R.E., Revised definition of Large Igneous Province (LIP). Earth and Planetary Science Letters, submitted.

Bryan, S.E., Constantine, A.E., Stephens, and C.J., Ewart, A., Schön, R.W., and Parianos, J. 1997, Early Cretaceous volcano-sedimentary successions along the eastern Australian continental margin: implications for the break-up of eastern Gondwana: Earth and Planetary Science Letters, v. 153 , pp. 85-102.

Bryan, S.E., Ewart, A., Stephens, C.J., Parianos, J., and Downes, P.J., 2000, The Whitsunday Volcanic Province, central Queensland, Australia: Lithological and stratigraphic investigations of a silicic-dominated large igneous province: Journal of Volcanology and Geothermal Research, v.99, pp. 55-78

Bryan, S.E., Ferrari, L., Reiners, P.W., Allen, C.M., Campbell, I.H., New insights into large volume rhyolite generation at the mid-Tertiary Sierra Madre Occidental Province, Mexico, revealed by U-Pb geochronology: Journal of Petrology, submitted.

Bryan, S.E., Riley, T.R., Jerram, D.A., Leat, P.T., and Stephens C.J., 2002, Silicic volcanism: an under-valued component of large igneous provinces and volcanic rifted margins, in Menzies, M.A., Klemperer, S.L., Ebinger, C.J., and Baker, J., eds, Magmatic Rifted Margins: Geological Society of America Special Paper, v. 362, pp. 99-120.

Bryan, S.E., Holcombe, R.J., and Fielding, C.R., 2003, Reply to: "The Yarrol terrane of the northern New England Fold Belt: Forearc or backarc?" Discussion by Murray, C.G., Blake, P. R., Hutton, L.J., Withnall, I.W., Hayward, M.A., Simpson, G.A., and Fordham, B.G.: Australian Journal of Earth Sciences, v. 50, pp. 271-293.

Cameron, K.L., Cameron, M., Bagby, W.C., Moll, E.J., and Drake, R.E., 1980, Petrologic characteristics of mid-Tertiary volcanic suites, Chihuahua: Geology, v.8, pp. 87-91.

Camprubi, A., Ferrari, L., Cosca, M.A., Cardellach, E., Canals, A., 2003, Ages of epithermal deposits in Mexico; regional significance and links with the evolution of Tertiary volcanism: Economic Geology, v. 98, no. 5, pp. 1029-1037.

Clarke, D.E., Paine, A.G.L., and Jensen, A.R., 1971, Geology of the Proserpine 1:250,000 Sheet area, Queensland: Bureau of Mineral Resources Geology and Geophysics Report, v. 144, 98p.

Cleverly, R.W., Betton, P.J., and Bristow, J.W., 1984, Geochemistry and petrogenesis of the Lebombo rhyolites, in: Erlank, A.J., ed., Petrogenesis of the volcanic rocks of the Karoo Province: Geological Society of South Africa Special Publication, v.13, pp. 171-194.

Coffin, M.F., and Eldholm, O., 1994, Large igneous provinces: crustal structure, dimensions, and external consequences: Reviews of Geophysics, v. 32, pp. $1-36$

Creaser, R.A., and White, A.J.R., 1991, Yardea Dacite-large volume, high temperature felsic volcanism from the Middle Proterozoic of South Australia: Geology, v. 19, pp. 48-51.

Dalziel, I.W.D., 1992, Antarctica a tale of two supercontinents?: Annual Review of Earth and Planetary Sciences, v. 20, pp. 501-526.

Dalziel, I.W.D., Lawver, L.A., Murphy, J.B., 2000, Plumes, orogenesis, and supercontinental fragmentation: Earth and Planetary Science Letters, v. 178 , pp. $1-11$.

Devine, J.D., Sigurdsson, H., Davis A.N., and Self, S. 1984, Estimates of sulfur and chlorine yield to the atmosphere from volcanic eruptions and potential climatic effects: Journal of Geophysical Research, B, v. 89, no. 7, pp. 6309-6325.

Ewart, A., Schön, R.W., and Chappell, B.W., 1992, The Cretaceous volcanicplutonic province of the central Queensland (Australia) coast-a rift related "calc-alkaline" province: Transactions of the Royal Society of Edinburgh, Earth Sciences, v. 83, pp. 327-345.

Ewart, A., Milner, S.C., Armstrong, R.A., and Duncan, A.R., 1998, Etendeka Volcanism of the Goboboseb Mountains and Messum Igneous Complex, Namibia. Part II: Voluminous quartz latite volcanism of the Awahab magma system: Journal of Petrology, v. 39, no. 2, pp. 227-253.

Ewart, A., Marsh, J.S., Milner, S.C., Duncan, A.R., Kamber, B.S., Armstrong, R.A., 2004, Petrology and geochemistry of Early Cretaceous biomodal continental flood volcanism of the NW Etendeka, Namibia; Part 2, Characteristics and petrogenesis of the high-Ti latite and high-Ti and low-Ti voluminous quartz latite eruptives, Journal of Petrology, v. 45, pp. 107-138.

Exon, N.F, Hill, P.J., Lafoy Y., Heine, C., and Bernardel, G., 2006, Kenn Plateau of northeast Australia: a continental fragment of the southwest Pacific jigsaw: Australian Journal ofEarth Sciences, v. 53, no. 4, pp. 541-564.

Fanning, C.M., Flint, R.B., Parker, A.J., Ludwig, K.R., and Blisset, A.H., 1988, Refined Proterozoic evolution of the Gawler Craton, South Australia, through U-Pb zircon geochronology: Precambrian Research, v. 40/41, pp. $363-386$.

Ferrari, L., Lopez-Martinez,.M., and Rosas-Elguera, J., 2002, Ignimbrite flare-up and deformation in the southern Sierra Madre Occidental, western Mexico; implications for the late subduction history of the Farallon Plate: Tectonics, v. 21, no. 17, pp. 1-23.

Ferrari, L., Valencia-Moreno, M., and Bryan S.E., 2006, Magmatism and Tectonics of the Sierra Madre Occidental and their relation to the evolution of the western margin of North America: Geological Society of America Special Paper, in press.

Frey, F.A., Coffin, M.F., Wallace, P.J., Weis, D., Zhao, X., Wise, S.W. Jr., Waehnert, V., Teagle, D.A.H., Saccocia, P.J., Reusch, D.N., Pringle, M.S., Nicolaysen, K.E., Neal, C.R., Mueller, R.D., Moore, C.L., Mahoney, J.J., Keszthelyi, L., Inokuchi, H., Duncan, R.A., Delius,H., Damuth, J.E., Damasceno, D., Coxall, H.K., Borre, M.K., Boehm, F., Barling, J., Arndt, N.T., and Antretter, M., 2000, Origin and evolution of a submarine large igneous province; the Kerguelen Plateau and Broken Ridge, southern Indian Ocean: Earth and Planetary Science Letters, v. 176, no. 1, pp. 73-89.

Gaina, C., Müller, R.D., Royer, J.Y., Stock, J., Hardebeck, J., and Symonds, P., 1998, The tectonic history of the Tasman Sea: a puzzle with 13 pieces: Journal of Geophysical Research, v. 103, pp. 12,413-12,433.

Gaina, C., Müller, R.D., Royer, J.Y., and Symonds, P., 1999, Evolution of the Louisiade triple junction: Journal of Geophysical Research, v. 104, pp. 12,927-12,940.

Giles, C.W., 1988, Petrogenesis of the Proterozoic Gawler Range Volcanics, South Australia: Precambrian Research, v. 40/41, pp. 407-427.

Grattan, J., 2005, Pollution and paradigms; lessons from Icelandic volcanism for continental flood basalt studies: Lithos, v. 79, no. 3-4, pp. 343-353.

Harris, C., and Milner, S., 1997, Crustal origin for the Paraná rhyolites: discussion of 'Description and petrogenesis of the Paraná rhyolites, southern Brazil' by Garland, F., Hawkesworth, C.J., Mantovani, M.S.M.: Journal of Petrology, v. 38, pp. 299-302.

Hattori, K., 1993, High-sulfur magma, a product of fluid discharge from underlying mafic magma; evidence from Mount Pinatubo, Philippines: Geology, v. 21, no.12, pp. 1083-1086.

Henry, C.D., and Aranda-Gomez, J.J., 2000, Plate interactions control middle-late Mioceneproto-Gulf and Basin and Range extension in the southern Basin and Range: Tectonophysics, v. 318, pp. 1-26.

Holton, J.R., Haynes, P.H., McIntyre, M.E., Douglass, A.R., Rood, R.B., Pfister, L., 1995, Stratosphere-troposphere exchange: Reviews of Geophysics, v. 33, no. 4, pp. 403-439.

Houghton, B.F., Wilson, C.J.N., McWilliams, M.O., Lanphere, M.A., Weaver, S.D., Briggs, R.M., and Pringle, M.S., 1995, Chronology and dynamics of a large silicic magmatic system: central Taupo Volcanic Zone, New Zealand: Geology, v. 23, pp.13-16.

Jolley, D.W. and Widdowson, M., 2005, Did Paleogene North Atlantic riftrelated eruptions drive early Eocene climate cooling?: Lithos, v. 79, pp. 355-366.

Kay, S.M., Ramos, V.A., Mpodozis, C., Sruoga P., 1989, Late Paleozoic to Jurassic silicic magmatism at the Gondwana margin: analogy to the Middle Proterozoic in North America?: Geology, v. 17, pp. 324-328.

Killian, R., Bieser, H., Behrmann, J., Baeza, O., Feq-Martin, M., Hohner, M., Schimpf D., Friedman A., and Mangini A., 2006, Millenium-scale vol- 
canic impact on superhumid and pristine ecosystem: Geology, v. 34, no. 8, pp. 609-612.

Kroenke, L.W., Wessel, P., and Sterling, A., 2004, Motion of the Ontong Java Plateau in the host-spot frame of reference:122 Ma-present, in Fitton, J.G., Mahoney, J.J., Wallace, P.J., and Saunders, A.D., eds, Origin and Evolution of the Ontong Java Plateau: Geological Society of London Special Publication, v. 229, pp. 9-20.

Lanphere, M.A., Cameron, K.L., and Cameron, M., 1980, Sr isotopic geochemistry of voluminous rhyolitic ignimbrites and related rocks, Batopilas area, western Mexico: Nature, v. 286, pp. 594-596.

Li, Z.X., Bogdanova, S.V., Collins, A.S., Davidson, A., De Waele, B., Ernst, R.E., Fitzsimons, I.C.W., Fuck, R.A., Gladkochub, D.P., Jacobs, J., Karlstrom, K.E., Lu, S., Natapov, L.M., Pease, V., Pisarevsky, S.A., Thrane, K., Vernikovsky, V., 2006, Assembly, configuration, and break-up history of Rodinia: a synthesis: Precambrian Geology, special issue (submitted).

Lightfoot, P.C., and Hawkesworth, C.J., 1997, Flood basalts and magmatic $\mathrm{Ni}, \mathrm{Cu}$, and PGE sulphide mineralization; comparative geochemistry of the Norilísk (Siberian Traps) and West Greenland sequences, in Mahoney, J.J., and Coffin, M.F., eds, Large igneous provinces; continental, oceanic, and planetary flood volcanism, Geophysical Monograph, v.100, pp. 357-380.

McCormick, M.P., Thomason, L.W. and Trepte, C.R., 1995. Atmospheric effects of the Mt. Pinatubo eruption: Nature, v. 373, pp. 399-404

McDowell, F.W. and Clabaugh, S.E., 1979, Ignimbrites of the Sierra Madre Occidental and their relation to the tectonic history of western Mexico: Geological Society of America Special Paper, v. 180, pp. 113-124.

Marsh, J.S., Ewart, A., Milner, S.C., Duncan, A.R., and Miller, R.McG., 2001, The Etendeka igneous province; magma types and their stratigraphic distribution with implications for the evolution of the ParanaEtendeka flood basalt province: Bulletin of Volcanology, v. 62, pp. 464-486.

Mason, B.G., Pyle, D.M., and Oppenheimer, C., 2004, The size and frequency of the largest explosive eruptions on Earth: Bulletin of Volcanology, v. 66, pp. 735-748.

Milner, S.C., Duncan, A.R., Whittingham, A.M., and Ewart, A., 1995, TransAtlantic correlation of eruptive sequences and individual silicic volcanic units within the Paraná-Etendeka igneous province: Journal of Volcanology and Geothermal Research, v. 69, pp. 137-157.

Mortimer, N., 2006, Zealandia: AESC2006, Melbourne, Australia.

Orr, T.H., 1994, The Mt Leyshon Gold Mine; geology and mineralisation, in Henderson, R.A., and Davis, B.K., eds, Extended conference abstracts; New developments in geology and metallogeny; northern Tasman orogenic zone: Contributions of the Economic Geology Research Unit, v. 50, pp. 29-35.

Pallister, J.S., Hoblitt, R.P., Meeker, G.P., Knight, R.J., and Siems, D.F., 1996, Magma mixing at Mount Pinatubo: petrographic and chemical evidence from the 1991 deposits, in Newhall, C.G., and Punongbayan, R.S., eds, Fire and Mud: Eruptions and Lahars of Mount Pinatubo, Philippines. Seattle: University of Washington Press, pp. 687-731.

Pankhurst, R.J. and Rapela, C.R., 1995, Production of Jurassic rhyolite by anatexis of the lower crust of Patagonia: Earth and Planetary Science Letters, v. 134, pp. 23-36.

Pankhurst, R.J., Leat, P.T., Sruoga, P., Rapela, C.W., Márquez, M., Storey, B.C., and Riley, T.R., 1998, The Chon Aike silicic igneous province of Patagonia and related rocks in Antarctica: a silicic large igneous province: Journal of Volcanology and Geothermal Research, v. 81, pp. $113-136$.

Pankhurst, R.J., Riley, T.R., Fanning, C.M., and Kelley, S.R., 2000, Episodic silicic volcanism along the proto-Pacific margin of Patagonia and the Antarctic Peninsula: plume and subduction influences associated with the break-up of Gondwana. Journal of Petrology, 41: 605-625.

Pearce, J.A., Harris, N.B.W., and Tindle, A.G., 1984, Trace element discrimination diagrams for the tectonic interpretation of granitic rocks: Journal of Petrology, v. 25, pp. 953-956.

Peate, D.W., 1997, The Paraná-Etendeka province, in Mahoney, J.J., Coffin, M., eds, Large Igneous Provinces: Continental, Oceanic, and Planetary Volcanism: Geophysical Monograph Series, v. 100, American Geophysical Union, pp. 217-245.

Perkins, C. and Kennedy, A.K., 1998, Permo-Carboniferous gold epoch of Northeast Queensland: Australian Journal of Earth Sciences, v. 45, no. 2, pp. 185-200.

Pirajno, F., 2006, Mantle dynamics and intraplate tectonics, magmatism and ore systems:IAVCEI 2006, International Conference on Continental Volcanism, Abstracts and Programs, May14-18, 2006 Guangzhou, China, p. 176.
Pirajno, F., Mantle plume models, intraplate magmatism and ore systems: Episodes, Vol.30, No.1.pp.6-19.

Preston, R.J., Hole, M.J., Still, J., and Patton, H., 1998, The mineral chemistry and petrology of Tertiary pitchstones from Scotland: Transactions of the Royal Society of Edinburgh: Earth Sciences, v. 89, pp. 95-111.

Pyle, D.M., 2000, Sizes of volcanic eruptions, in Sigurdsson, H. et al. eds., Encyclopedia of volcanoes: Academic Press, pp 263-269.

Richards, M.A., Duncan, R.A., Courtillot, V.E., 1989, Flood basalts and hotspot tracks; plume heads and tails. Science, v. 246, no. 4926, pp. 103-107.

Riley, T.R., and Leat, P.T., 1999, Large volume silicic volcanism along the proto-Pacific margin of Gondwana: lithological and stratigraphical investigations from the Antarctic Peninsula: Geological Magazine, v. 136, pp. $1-16$.

Riley, T.R., Leat, P.T., Pankhurst, R.J., and Harris, C., 2001, Origins of large volume rhyolitic volcanism in the Antarctic Peninsula and Patagonia by crustal melting: Journal of Petrology, v. 42, pp. 1043-1065.

Roberts, M.P., and Clemens, J.D., 1993, Origin of high-potassium, calc-alkaline, I-type granitoids: Geology, v. 21, pp. 825-828.

Robock, A., 2000, Volcanic eruptions and climate: Reviews of Geophysics, v. 38, no.2, pp. 191-219.

Schalamuk, I.B., Zubia, M., Genini, A., and Fernandez, R.R., 1997, Jurassic epithermal $\mathrm{Au}-\mathrm{Ag}$ deposits of Patagonia, Argentina: Ore Geology Reviews, v. 12, no. 3, pp. 173-186.

Self, S., Thordarson, T., Keszthelyi, L., 1997, Emplacement of continental flood basalt lava flows, in Mahoney, J.J., Coffin, M., eds, Large Igneous Provinces: Continental, Oceanic, and Planetary Volcanism: Geophysical Monograph Series, v. 100, American Geophysical Union, pp. 381-410.

Self, S., Thordarson, T. and Widdowson, M., 2005, Gas Fluxes from Flood Basalt Eruptions: Elements, v. 1, pp. 283-287.

Sharma, K.K., 2004, The Neoproterozoic Malani magmatism of the northwestern Indian shield: implications for crust-building processes: Proceedings of the Indian Academy of Sciences: Earth and Planetary Sciences, v. 113, no. 4, pp. 795-807.

Sharma, K.K., 2005, Malani magmatism: An extensional lithospheric tectonic origin, in Foulger, G.R., Natland, J.H., Presnall D.C., Anderson, D.L., eds, Plates, Plumes and Paradigms: Geological Society of America Special Paper, v. 388, pp. 463-476.

Sharma, K., Blake, S., Self, S., and Krueger, A.J., 2004, $\mathrm{SO}_{2}$ emissions from basaltic eruptions, and the excess sulfur issue: Geophysical Research Letters, v. 31, no. 13 .

Skilling, I.P., White, J.D.L, Bryan, S.E., Ross, P.-S., and Self, S., 2007, Physical volcanology of Large Igneous Provinces: a review: Journal of Volcanology and Geothermal Research, in press.

Staude, J.M.G., and Barton, M.D., 2001, Jurassic to Holocene tectonics, magmatism, and metallogeny of northwestern Mexico: Geological Society of America Bulletin, v. 113, no.10, pp. 1357-1374.

Stephenson, P.J., 1990, Some aspects of dyke emplacement and characteristics in the Townsville-Ingham District, North Queensland, Australia, in Parker, A.J., Rickwood, P.C., and Tucker, D.H., eds, Mafic dykes and Emplacement Mechanisms, Proceedings of the Second International Dyke Conference: A.A. Balkema, Rotterdam-Brookfield, no. 2, pp. 421-430.

Stothers, R.B., Wolff, J.A., Self, S., and Rampino M.R., 1986, Basaltic fissure eruptions, plume heights, and atmospheric aerosols: Geophysical Research Letters, v. 13, no. 8, pp. 725-728.

Sutton, A.N., Blake, S., and Wilson, C.J.N., 1995, An outline geochemistry of rhyolite eruptives from Taupo volcanic centre, New Zealand: Journal of Volcanology and Geothermal Research, v. 68, pp. 153-175.

Swanson, E.R., Keizer, R.P., Lyons, J.I., and Clabaugh, S.E., 1978, Tertiary volcanism and caldera development near Durango City, Sierra Madre Occidental, Mexico: Geological Society of America Bulletin, v. 89, pp. 1000-1012.

Swanson, E.R., and McDowell, F.W., 1984, Calderas of the Sierra Madre Occidental volcanic field western Mexico. Journal of Geophysical Research, v. 89, pp. 8787-8799.

Swanson, E.R., and McDowell, F.W., 2000, Sierra Madre Occidental volcanic field; a history of field studies: Abstracts with Programs, Geological Society of America, v. 32, pp. 467468.

Swanson, E.R., Kempter, K.A., McDowell, F.W., and McIntosh, W.C., 2006, Major ignimbrites and volcanic centers of the Copper Canyon area; a view into the core of Mexico's Sierra Madre Occidental: Geosphere, v. 2, pp. 125-141.

Thorne, A.M., and Trendall, A.F., 2001, Geology of the Fortescue Group, Pilbara Craton, Western Australia: Bulletin of the Geological Survey of Western Australia, v.144, pp.1-249. 
Thordarson, T., and Self, S., 1998, The Rosa Member, Columbia River Basalt Group: A gigantic pahoehoe lava flow field formed by endogenous processes?: Journal of Geophysical Research, v. 103, no. B11, pp. 27,411-27,445.

Thordarson, T. and Self, S., 2003, Atmospheric and environmental effects of the 1783-1784 Laki eruption; a review and reassessment: Journal of Geophysical Research, D, Atmospheres, v. 108, no. pp. 1-29.

Twist, D., and French, B.M., 1983, Voluminous acid volcanism in the Bushveld Complex: a review of the Rooiberg Felsite: Bulletin of Volcanology, v. 46, pp. 225-242.

Ukstins Peate, I., Baker, J.A., Al-Kadasi, M., Al-Subbary, A., Knight, K.B., Riisager, P., Thirlwall, M.F., Peate, D.W., Renne, P.R., and Menzies, M.A., 2005, Volcanic stratigraphy of large-volume silicic pyroclastic eruptions during Oligocene Afro-Arabian flood volcanism in Yemen: Bulletin of Volcanology, v. 68, pp. 135-156.

Wallace, P.J., 2001, Volcanic $\mathrm{SO}_{2}$ emissions and the abundance and distribution of exsolved gas in magma bodies: Journal of Volcanology and Geothermal Research, v. 108, pp. 85-106.

Wark, D.A., 1991, Oligocene ash flow volcanism, northern Sierra Madre Occidental: Role of mafic and intermediate-composition magmas in rhyolite genesis: Journal of Geophysical Research, v. 96, pp. 13,389-13,411.

Westrich, H.R., and Gerlach, T.M., 1992, Magmatic gas source for the stratospheric $\mathrm{SO}_{2}$ cloud from the June 15, 1991, eruption of Mount Pinatubo: Geology, v. 20, no. 10, pp. 867-870.

White, J.D.L. and Houghton, B.F., 2006, Primary volcaniclastic rocks:Geology, v. 34, no. 8, pp. 677 680 .

Wignall, P.B., 2001, Large igneous provinces and mass extinctions: EarthScience Reviews, v. 53, pp. 1-33.

Wignall, P.B., 2005, The link between Large Igneous Province eruptions and mass extinctions: Elements, v. 1, pp. 293-297.

Wilson, C.J.N., Houghton, B.F., McWilliams, M.O., Lanphere, M.A., Weaver, S.D., and Briggs, R.D., 1995, Volcanic and structural evolution of Taupo Volcanic Zone, New Zealand: a review: Journal of Volcanology and Geothermal Research, v. 68, pp. 1-28.
Yale, L.B., and Carpenter, S.J., 1998, Large igneous provinces and giant dike swarms: proxies for supercontinent cyclicity and mantle convection: Earth and Planetary Science Letters, v. 163, pp. 109ᄀ122.

Zhaw, K., Hunns, S.R., Large, R.R., Gemmell, J.B., Ryan, C.G., and Mernagh, T.P., 2003, Microthermometry and chemical composition of fluid inclusions from the Mt Chalmers volcanic-hosted massive sulfide deposits, central Queensland, Australia; implications for oregenesis: Chemical Geology, v. 194, no.1-3, 225-244.

Scott Bryan is Senior Lecturer in Geosciences at Kingston University, UK. He obtained his PhD from Monash University in 1999 having worked on Quaternary phonolitic explosive volcanism at Tenerife (Canary Islands). His main research focus has been on silicic magmatism in Large Igneous Provinces, and his research on the Early Cretaceous Whistunday igneous province led to the recognition that LIP events can be silicic-dominated, and that the eastern margin of Australia is a volcanic rifted margin. His research continues on several important aspects of silicic magmatism during LIP events, in particular the petrogenesis and rates of silicic magma generation, and the eruptive and emplacement mechanisms to understand the environmental and climatic impacts from the silicic eruptions.

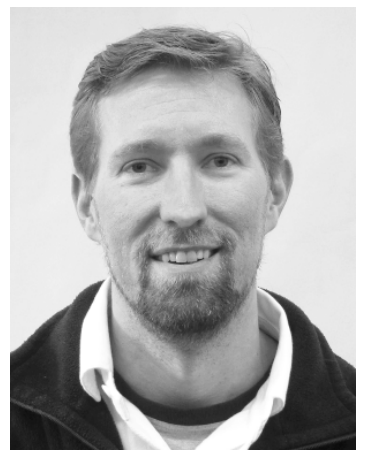

\section{Hutchison 'Young Scientist' Fund}

William Watt Hutchison, "Hutch" to his many friends around the world, was a Scots-born Canadian geologist who served Canada and the IUGS in myriad dynamic and creative ways. Most notably, he served as the IUGS Secretary General (1976-1980) at a pivotal time in its history, and as IUGS President (1984-1987). The same boundless energy, enthusiasm, skill in communications, and ability to foster teamwork that characterized his work with the IUGS also carried him to preeminent scientific administrative positions in the Canadian Government, where he served as Director General of the Geological Survey of Canada and as Assistant Deputy Minister of Earth Sciences. His distinguished career was terminated in 1987 by his untimely death at the age of 52, following a painful struggle with cancer.

One of Hutch's last wishes was to establish under IUGS auspices a memorial foundation intended to promote the professional growth of deserving, meritorious young scientists from around the world by supporting their participation in important IUGS-sponsored conferences. The first 3 beneficiaries of the Hutchison "Young Scientist" Foundation attended the 28th International Geological Congress (IGC) in Washington, D.C., in 1989.

Initially, earned interest on the funds available to the Hutchison Foundation were insufficient to sustain comparable grants every four years without seriously eroding the principal. For that reason, the IUGS made no grants from the Foundation for the 30th IGC (1996), preferring instead to strengthen the fund by allowing it to earn interest for a longer period of time and by appealing for donations from the international geologic community. Grants from the Foundation again supported deserving young scientists beginning with the 31st IGC (2000), and should continue for future Congresses. The IUGS would like to expand the resources of the Foundation to make it possible also to offer support to deserving young scientists to attend other important IUGS-sponsored scientific meetings. The Hutchison "Young Scientist" Foundation is a worthy cause that honors a fine, caring man and a distinguished, public-spirited scientist and administrator. The foundation also celebrates and promotes those things that gave Hutch the most professional satisfaction: geology, international scientific collaboration, and stimulating young minds.

The IUGS welcomes contributions to the Hutchison "Young Scientist" Foundation. Please send donations to:

Dr. Antonio Brambati

IUGS Treasurer

Dept. of Geological, Environmental and Marine Sci. (DiSGAM),

University of Trieste, 1-34127 Trieste, ITALY

Tel: +39040 558 2046; Fax: +39040 5582048

E-mail: brambati@univ.trieste.it

Checks in US dollars or Visa/Mastercard (please include account number and expiration date) are preferred in order to avoid the high cost of currency conversions. Residents of the U.S.A. are reminded that charitable gifts of this nature are tax deductible. 